\title{
STRUKTUR KEPEMILIKAN DAN CHARTER VALUE SEBAGAI PEMODERASI PENGARUH CAPITAL REQUIREMENT PADA PENGAMBILAN RISIKO BANK
}

\author{
I Gusti Ayu Nyoman Budiasih \\ Jessika Jesslyn \\ Anak Agung Ngurah Bagus Dwirandra \\ Fakultas Ekonomi dan Bisnis Universitas Udayana \\ Jl. P. B. Sudirman Denpasar Bali - Indonesia, Kode pos: 80113
}

\begin{abstract}
The objective of this research was to get empirical evidence about the effect of capital requirement on bank risk taking which is moderated by ownership structure and charter value. This research used commercial banks that listed on Bursa Efek Indonesia (BEI) in the period 2008-2014. The sample selection used purposive sampling method. The final sample amounted to 22 banks. Hypothesis testing done by multiple linear regression and moderated regression analysis (MRA). The result showed positive and significant effect of capital requirement on bank risk-taking. Moreover, the ownership structure can't moderate the effect of capital requirement on bank risk-taking. The same condition was found that charter value was not able to moderate the effect of capital requirement on bank risk-taking.
\end{abstract}

Keywords: Capital requirement, ownership structure, charter value, bank risk taking

\section{PENDAHULUAN}

Bank sebagai lembaga yang mengemban fungsi intermediasi dihadapkan pada berbagai risiko usaha yang mesti dikelola agar mampu meminimalisir potensi kerugian. Oleh karena itu, Bank Indonesia telah mengeluarkan peraturan sebagai pedoman manajemen risiko bank, seperti Peraturan Bank Indonesia (PBI) Nomor 11/25/ PBI/2009. Langkah ini diharapkan mampu mengon- trol manajemen puncak dan menumbuhkan budaya prudential dalam lingkungan internal bank (Otoritas Jasa Keuangan, 2014).

Risiko merupakan potensi adanya kerugian akibat peristiwa-peristiwa tertentu yang terjadi. Produk dan aktivitas bank yang makin kompleks mengindikasikan bahwa risiko yang dihadapi makin tinggi pula (Setiawan, 2007). Pengambilan risiko dilatarbelakangi oleh keinginan memperoleh ke-

Korespondensi dengan Penulis:

I Gusti Ayu Nyoman Budiasih HP: +6281338693296, Fax: (0361) 224133

e-mail: iganbudiasih@yahoo.com 
untungan yang sepadan dengan biaya yang dikeluarkan. Tindakan ini mencerminkan kemauan suatu organisasi untuk menggapai peluang yang ada dengan hasil akhir berupa keuntungan atau kerugian.

Beberapa peneliti mengemukakan bahwa besarnya pengambilan risiko bank dipengaruhi oleh regulasi yang diterapkan pemerintah (Ongena dkk., 2013; Gonzales, 2005; Repullo, 2004). Regulasi sebagai bagian dari kontrol untuk menekan konflik keagenan diharapkan dapat mendorong bank bersikap hati-hati dalam pengambilan risiko (Taswan, 2012). Regulasi perbankan dalam penelitian ini difokuskan pada kebijakan capital requirement. Capital requirement berfungsi sebagai buffer (penyangga) saat terjadi krisis yang menganggu stabilitas sistem keuangan. Selain itu, disusunnya peraturan modal ini dilatarbelakangi oleh kekhawatiran mengenai jumlah modal yang dimiliki bank kurang dari tingkat relatif optimal terhadap risiko-risiko usaha yang dihadapi bank tersebut (Awdeh dkk., 2011).

Peraturan modal yang telah dirancang sedemikian rupa tidak sepenuhnya mampu mengurangi pengambilan risiko bank. Awdeh dkk. (2011) menemukan bahwa capital requirement berpengaruh positif pada pengambilan risiko bank. Peningkatan pengambilan risiko terjadi ketika tingkat persyaratan modal minimum mengalami kenaikan. Ini disebabkan karena penerapan peraturan tersebut memicu penurunan expected profits dan sebagai akibatnya bank memilih berinvestasi pada aset berisiko. Hal yang serupa juga disampaikan oleh Blum (1999) bahwa capital adequacy requirement secara aktual dapat meningkatkan risiko.

Penelitian mengenai pengaruh capital requirement dan pengambilan risiko bank telah banyak diuji sebelumnya dan hasil yang ditemukan cukup bervariasi. Koehn dan Santomero (1980) menemukan bahwa peraturan modal gagal mengurangi probability of default bank. Kemudian, Gennotte dan Pyle (1991) menyatakan bahwa per- aturan modal dapat meningkatkan portfolio risk dan probability of default bank. Sebaliknya, hasil penelitian yang berbeda disampaikan oleh Konishi dan Yasuda (2004) bahwa pengimplementasian capital adequacy requirement mengurangi pengambilan risiko pada bank-bank komersial. Agoraki dkk. (2011) juga menemukan bahwa capital requirement mengurangi risiko secara umum. Selain itu, temuan penelitian yang diperoleh Berger dkk. (2014) menjelaskan bahwa intervensi regulasi dan capital support mampu menurunkan pengambilan risiko bank.

Hasil-hasil penelitian terdahulu yang tidak konsisten diduga karena ada variabel lain yang ikut berpengaruh dalam hubungan variabel bebas dengan variabel terikat. Murray (1990) menjelaskan bahwa agar dapat merekonsiliasi hasil yang saling bertentangan diperlukan pendekatan kontingensi untuk mengindentifikasi variabel lain yang bertindak sebagai pemoderasi. Penelitian ini menggunakan struktur kepemilikan dan charter value sebagai variabel pemoderasi.

Struktur kepemilikan ditentukan dari persentase kepemilikan saham dalam suatu perusahaan. Sesuai dengan riset yang dilakukan oleh Laeven dan Levine (2009), struktur kepemilikan dalam penelitian ini dilihat dari perspektif shareholder. Dengan kepemilikan saham yang besar, shareholder mempunyai hak kontrol dan hak aliran kas yang besar pula (ini disebut dengan large shareholder). Large shareholder memiliki pengaruh yang signifikan pada keputusan finansial dan dapat membentuk perilaku pengambilan risiko (Paligorova, 2010). Bila dalam suatu bank terdapat large shareholder, dapat diperkirakan bahwa regulasi yang diberlakukan bukannya menurunkan risiko, tetapi cenderung menimbulkan peningkatan pengambilan risiko (Laeven dan Levine, 2009).

Charter value sebagai variabel pemoderasi lainnya merupakan nilai sekarang dari keuntungan masa depan yang diharapkan perusahaan. Seperti yang diungkapkan oleh Jokipii (2008), charter value dapat membantu mengurangi pengambilan risiko 


\section{Jurnal Keuangan dan Perbankan | KEUANGAN}

Vol. 20, No.3, September 2016: 428-437

yang berlebihan. Bank dengan charter value yang tinggi akan beroperasi lebih hati-hati dan memilih strategi bisnis yang rendah risiko untuk mengurangi kemungkinan penurunan charter value. Oleh karena itu, pengaruh positif capital requirement pada pengambilan risiko akan melemah dengan meningkatnya charter value yang dimiliki bank. Awalnya, ketatnya regulasi yang diterapkan akan meningkatkan risiko bank. Namun, pengalokasian modal yang cukup besar untuk mematuhi capital requirement menyebabkan kenaikan cash flow yang diikuti dengan peningkatan charter value sehingga bank cenderung memilih berinvestasi pada proyek yang aman (Milne dan Whalley, 2001). Pernyataan yang berbeda disampaikan oleh Hellmann dkk. (2000) bahwa tingginya capital requirement menyebabkan kenaikan cost of capital dan menurunkan return dari kegiatan lending bank. Tingkat charter value pun akan menurun dan mendorong bank untuk mengambil risiko yang lebih besar.

Penelitian ini merupakan pengembangan dari riset Laeven dan Levine (2009) yang menguji hubungan antara pengambilan risiko, struktur kepemilikan, dan regulasi bank. Penambahkan charter value sebagai variabel moderasi didasarkan dari penelitian Milne dan Whalley (2001). Di Indonesia, pengambilan risiko bank belum banyak diteliti dalam riset-riset akuntansi. Hal inilah yang mendorong dilakukannya pengujian mengenai apakah capital requirement berpengaruh pada pengambilan risiko bank serta bagaimana kemampuan struktur kepemilikan dan charter value dalam memoderasi pengaruh capital requirement pada pengambilan risiko bank.

\section{HIPOTESIS}

Bank Indonesia selaku otoritas pengawas menetapkan peraturan permodalan minimum (capital requirement) untuk memastikan tiap-tiap bank mempunyai modal yang cukup dalam mendukung kegiatan usahanya (Indroes, 2011: 68). Gennotte dan Pyle (1991) menjelaskan bahwa tujuan adanya capital requirement adalah untuk membatasi kemampuan bank dalam meningkatkan pengambilan risiko. Tetapi, bank memilih untuk mengalihkan investasinya ke aset berisiko ketika regulator memperketat peraturan modal ini. Hal tersebut dikarenakan modal adalah sumber daya yang mahal dan dapat meningkatkan cost of capital. Bank diwajibkan untuk menahan modal dengan jumlah yang cukup tinggi akan terdorong mengambil risiko yang besar sebagai kompensasi atas banyaknya biaya yang dikeluarkan. Ini didukung dengan hasil penelitian Koehn dan Santomero (1980), Blum (1999), dan Awdeh dkk. (2011) yang menunjukkan adanya pengaruh positif capital requirement pada risiko bank secara umum. Namun, temuan yang berbeda disampaikan Konishi dan Yasuda (2004), Agoraki dkk. (2011), dan Berger dkk. (2014) bahwa regulasi modal mampu menurunkan risiko bank. Berdasarkan pemaparan ini, maka disusun hipotesis sebagai berikut.

$\mathrm{H}_{1}$ : Capital requirement berpengaruh positif pada pengambilan risiko bank.

Laeven dan Levine (2009) mengemukakan bahwa struktur kepemilikan berinteraksi dengan capital regulation dalam membentuk perilaku pengambilan risiko bank. Large shareholder mempengaruhi keputusan yang diambil bank dalam menanggapi penerapan peraturan modal. Ketatnya capital requirement memungkinkan terjadinya pengambilan risiko yang berlebihan. Large shareholder mengkompensasikan hilangnya utilitas mereka dari penerapan persyaratan modal dengan mempengaruhi pihak manajemen untuk memilih berinvestasi pada portofolio yang berisiko. Hal ini terjadi saat bank mempunyai large shareholder yang cukup kuat.

$\mathrm{H}_{2}$ : Struktur kepemilikan memperkuat pengaruh capital requirement pada pengambilan risiko bank. 
Bank dengan charter value yang besar cenderung mempertahankan nilai tersebut dan memilih strategi bisnis yang tidak begitu berisiko (Bigg, 2003). Pelaksanaan capital requirement memicu bank melakukan moral hazard dengan mengambil risiko yang berlebihan untuk mengimbangi cost of capital yang dikeluarkan. Di sinilah peran charter value dalam mengurangi masalah moral hazard. Bank yang memperhitungkan charter value cenderung menurunkan risiko demi menghindari kondisi default yang dapat memperkecil keuntungan di masa depan. Dengan demikian, charter value mengurangi pengaruh positif capital requirement terhadap pengambilan risiko (Milne dan Whalley, 2001).

$\mathrm{H}_{3}$ : Charter value memperlemah pengaruh capital requirement pada pengambilan risiko bank.

\section{METODE}

Penelitian dilakukan pada bank-bank komersial yang go public di tahun 2008-2014. Data yang digunakan berupa data sekunder yang didapatkan dari Otoritas Jasa Keuangan (OJK) dan Bursa Efek Indonesia (BEI). Populasi penelitian yakni semua bank komersial yang listed di BEI. Penyeleksian sampel menggunakan teknik nonprobability sampling dengan pendekatan purposive sampling.

Pengambilan risiko bank merupakan pilihan keputusan bisnis yang meningkatkan volatilitas keuntungan bank (De Nicolo dkk., 2010). Variabel ini diukur dengan logaritma natural dari nilai $z$ score yang didasarkan pada penelitian Laeven dan Levine (2009).

$$
z \text {-score } \square \square \frac{R O A+C A R}{\sigma(R O A)}
$$

$$
\begin{aligned}
& \mathrm{ROA}=\frac{\text { laba bersih sebelum pajak }}{\text { total aktiva }} \\
& \mathrm{CAR}=\frac{\text { modal bank }}{\text { total ATMR (Aktiva Tertimbang Menurut Risiko })}
\end{aligned}
$$

$$
\sigma(\mathrm{ROA})=\sqrt{\text { varians } R O A^{2}}
$$

Capital requirement adalah persyaratan modal minimum yang wajib dipenuhi oleh bank. Capital requirement diperoleh dari rasio Kewajiban Penyediaan Modal Minimum (KPMM), dimana makin tinggi KPMM suatu bank maka makin baik kemampuan bank dalam mengantisipasi risiko yang tidak diinginkan dan sebaliknya (Taswan, 2012).

Struktur kepemilikan menunjukkan jumlah kepemilikan saham oleh insider (manajemen) serta outsider (investor). Variabel ini diukur dari persentase saham large shareholder dalam bank yang didasarkan pada penelitian Fallah dan Dolatabadi (2015).

Charter value merupakan nilai sekarang dari future profit yang diharapkan bank (Demsetz dkk., 1996). Charter value diperoleh dari rasio market-tobook-value of assets (Jokipii, 2008 dan Fisher dkk., 2001). Makin tinggi MBVA bank maka makin tinggi pula charter value yang dimilki, sebaliknya MBVA yang rendah mengindikasikan charter value yang rendah pula.

MBVA $=\frac{\text { (Total Asset }- \text { Book Value of Equity }+ \text { Market Value of Equity })}{\text { Total Asset }}$

Sebelum dilakukan analisis data, dilakukan pengujian model dengan asumsi klasik. Pengujian tersebut terdiri dari uji autokorelasi, uji normalitas, uji multikolinieritas, dan uji heterokesdastisitas. Analisis regresi linear berganda digunakan dalam menguji Hipotesis 1 sedangkan Hipotesis 2 dan Hipotesis 3 diuji menggunakan moderated regression analysis (MRA).

Persamaan 1:

$Z_{\text {it }}=\alpha+\beta_{1}$ CapReq $+\beta_{2}$ Shareholder $+\beta_{3}$ Charter $+\mathrm{e}$.

Persamaan 2:

$Z_{\text {it }}=\alpha+\beta_{1}$ CapReq $+\beta_{2}$ Shareholder $+\beta_{3}$ Charter $+\beta_{4}$ CapReq ${ }^{*}$ Shareholder $+\beta_{5}$ CapReq ${ }^{*}$ Charter $+\mathrm{e}$ 


\section{Jurnal Keuangan dan Perbankan | KEUANGAN}

Vol. 20, No.3, September 2016: 428-437

Keterangan:

$\begin{array}{ll}\alpha & =\text { konstanta } \\ \beta_{1,} \beta_{2,} \beta_{3,}, \beta_{4,} \beta_{5} & =\text { koefisien regresi } \\ \mathrm{Z}_{\mathrm{it}} & \text { pengambilan risiko pada } \\ & \text { bank ke-i dan tahun ke- } \mathrm{t} \\ \text { CapReq } & \text { capital requirement } \\ \text { Shareholder } & \text { large shareholder } \\ \text { CapReq* Shareholder }= & \text { interaksi antara capital require- } \\ & \text { ment dengan struktur kepe- } \\ & \text { milikan } \\ = & \text { interaksi antara capital re- } \\ \text { CapReq*Charter } & \text { quirement dengan charter } \\ & \text { value } \\ = & \text { error }\end{array}$

HASIL

Setelah dilakukan penyeleksian sesuai kriteria yang ditentukan, sampel akhir berjumlah 22 bank dengan periode penelitian 7 tahun. Total observasi adalah 154 pengamatan. Data yang telah terkumpul dideskripsikan pada hasil statistik deskriptif pada Tabel 2.

Model yang digunakan dalam menganalisis pengaruh capital requirement pada pengambilan risiko bank adalah analisis regresi linear berganda. Hasil pengolahan data disajikan pada Tabel 3.

Output regresi ditunjukkan pada kolom $\mathrm{F}$ diperoleh $P_{\text {value }}$ sebesar 0.020 . Nilai $P_{\text {value }}$ ini di bawah nilai alpha $(0,05)$, sehingga model regresi memenuhi kriteria fit model. Adjusted $R$ Square sebesar 0,045 menunjukkan bahwa $4,5 \%$ variasi dari variabel pengambilan risiko bank dipengaruhi oleh variasi dari variabel capital requirement, struktur kepemilikan, dan charter value, sedangkan sisanya 95,5\% dipengaruhi oleh variabel-variabel lain yang tidak disertakan dalam model. Transformasi data yang dilaksanakan untuk memenuhi syarat uji autokorelasi menyebabkan perubahan model regresi sebagai berikut.

Tabel 2. Statistik Deskriptif

\begin{tabular}{ccccc}
\hline Keterangan & Pengambilan risiko & Capital requirement & Struktur kepemilikan & Charter value \\
\hline Maksimum & 6,5623 & 0,4649 & 0,9896 & 1,6004 \\
Minimum & $-3,2702$ & 0,0802 & 0,0487 & 0,8746 \\
Rata-rata & 4,4072 & 0,1691 & 0,5418 & 1,0874 \\
Std. Deviasi & 1,1367 & 0,06 & 0,2143 & 0,1415 \\
\hline
\end{tabular}

Sumber: Data diolah, 2015

Tabel 3. Analisis Regresi Linear Berganda

\begin{tabular}{|c|c|c|c|c|c|}
\hline & & Constant & Capital requirement & $\begin{array}{c}\text { Struktur } \\
\text { kepemilikan }\end{array}$ & Charter value \\
\hline \multirow{2}{*}{$\begin{array}{c}\text { Unstandardized } \\
\text { Coef. }\end{array}$} & B & 2,132 & 3,811 & $-0,894$ & $-0,147$ \\
\hline & $\begin{array}{l}\text { Std. } \\
\text { Error }\end{array}$ & 0,384 & 0,461 & 0,500 & 0,699 \\
\hline $\begin{array}{c}\text { Standardized } \\
\text { Coef. }\end{array}$ & Beta & & 0,214 & $-0,142$ & $-0,017$ \\
\hline \multicolumn{2}{|l|}{ Sig. } & 0,000 & 0,010 & 0,076 & 0,834 \\
\hline \multicolumn{3}{|c|}{ Hasil Pengujian } & Diterima & - & - \\
\hline \multicolumn{3}{|c|}{ Adjusted R Square } & \multicolumn{3}{|c|}{0,045} \\
\hline \multicolumn{3}{|c|}{$\mathbf{F}$} & & 0,020 & \\
\hline
\end{tabular}

Sumber: Data diolah, 2015 


\section{Struktur Kepemilikan dan Charter Value sebagai Pemoderasi Pengaruh Capital Requirement...}

I Gusti Ayu Nyoman Budiasih, Jessika Jesslyn, \& Anak Agung Ngurah Bagus Dwirandra

$Z_{t}-\rho Z_{t-1}=2,132+3,811\left(\operatorname{CapReq}_{\mathrm{t}}-\rho \operatorname{CapReq} \mathrm{T}_{\mathrm{t}-1}\right)-0,894$

$\left(\right.$ Shareholder $_{\mathrm{t}}-\rho$ Shareholder $\left._{\mathrm{t}-1}\right)$ -

$0,147\left(\right.$ Charter $_{\mathrm{t}}-\rho$ Charter $\left._{\mathrm{t}-1}\right)$

Tabel 3 menunjukkan probability value uji 1 arah variabel capital requirement adalah 0,005 berada di bawah nilai alpha $(0,05)$. Temuan tersebut membuktikan bahwa capital requirement berpengaruh pada pengambilan risiko bank secara signifikan. Nilai koefisien regresi sebesar 3,811 menunjukkan arah pengaruh variabel bebas pada variabel terikat adalah positif. Dengan demikian, dapat disimpulkan bahwa Hipotesis 1 diterima.

Hasil uji MRA disajikan dalam Tabel 4 berikut.

Pada uji F diperoleh $P_{\text {value }} 0,049$ di bawah nilai 0,05 , sehingga model regresi memenuhi kriteria fit model. Di samping itu, Adjusted R Square sebesar 0,040 menjelaskan $4 \%$ variasi pengambilan risiko bank dapat dijelaskan variasi variabel capital requirement, struktur kepemilikan, charter value, serta moderasi, sedangkan sisanya $96 \%$ dijelaskan faktor-faktor lain di luar model. Berdasarkan hasil uji MRA, disusun persamaan regresi berikut.

$\mathrm{Z}_{\mathrm{t}}-\tilde{\mathrm{n}} \mathrm{Z}_{\mathrm{t}-1}=1,980+5,899\left(\operatorname{CapReq}_{\mathrm{t}}-\rho \operatorname{CapReq}_{\mathrm{t}-1}\right)-$ 1,636 (Shareholder $r_{t}-\rho$ Shareholder $\left.r_{t-1}\right)+$ $0,456\left(\right.$ Charter $_{t}-\rho$ Charter $\left.{ }_{t-1}\right)+8,683$ $\left(\text { CapReq }_{\mathrm{t}}-\rho \text { CapReq }_{\mathrm{t}-1}\right)^{*}$ (Shareholder ${ }_{\mathrm{t}}-$ $\rho$ Shareholder $\left.{ }_{\mathrm{t}-1}\right)-$ 7,368 (CapReq - $_{\mathrm{t}}$ $\rho$ CapReq $\left._{\mathrm{t}-1}\right) *\left(\right.$ Charter $_{\mathrm{t}}-\rho$ Charter $\left._{\mathrm{t}-1}\right)$
Uji MRA menunjukkan probability value interaksi antara capital requirement dan struktur kepemilikan adalah 0,305 berada di atas nilai alpha $(0,05)$. Temuan penelitian ini menunjukkan bahwa struktur kepemilikan tidak mampu memoderasi pengaruh capital requirement pada pengambilan risiko bank secara signifikan. Jadi, disimpulkan bahwa Hipotesis 2 ditolak. Pada Tabel 3 diketahui bahwa struktur kepemilikan berpengaruh pada pengambilan risiko bank secara signifikan. Ini dibuktikan dengan probability value 0,038 di bawah nilai alpha $(0,05)$. Sesuai dengan pengelompokkan variabel moderasi yang disampaikan oleh Sharma et al. (1981) dalam Ghozali (2006:224), struktur kepemilikan bukanlah moderator melainkan tergolong ke dalam prediktor.

Di samping itu, pada Tabel 4 diketahui bahwa probability value interaksi antara capital requirement dan charter value adalah 0,396 di atas nilai alpha $(0,05)$. Temuan tersebut menunjukkan bahwa charter value tidak mampu memoderasi pengaruh capital requirement pada pengambilan risiko bank secara signifikan. Dengan demikian, dapat ditarik kesimpulan bahwa Hipotesis 3 ditolak. Pada Tabel 3 diketahui bahwa charter value tidak berpengaruh pada pengambilan risiko bank secara signifikan. Ini dibuktikan dengan probability value 0,417 berada di atas nilai alpha $(0,05)$. Dengan demikian, charter value termasuk dalam variabel moderasi dengan tipe homologizer.

Tabel 4. Moderated Regression Analysis (MRA)

\begin{tabular}{|c|c|c|c|c|c|c|c|}
\hline & & Const. & Capital req. & $\begin{array}{c}\text { Struktur } \\
\text { kepemilikan }\end{array}$ & $\begin{array}{l}\text { Charter } \\
\text { value }\end{array}$ & $\begin{array}{c}\text { CapReq* } \\
\text { Shareholder }\end{array}$ & $\begin{array}{c}\text { CapReq* } \\
\text { Charter }\end{array}$ \\
\hline \multirow{2}{*}{$\begin{array}{l}\text { Unstdzd } \\
\text { Coef. }\end{array}$} & B & 1,980 & 5,899 & $-1,636$ & 0,456 & 8,683 & $-7,368$ \\
\hline & $\begin{array}{l}\text { Std. } \\
\text { Error }\end{array}$ & 0,646 & 5,090 & 0,918 & 1,109 & 8,439 & 8,664 \\
\hline \multirow{2}{*}{$\begin{array}{l}\text { Stdzd } \\
\text { Coef. } \\
\qquad \text { Si }\end{array}$} & Beta & & 0,331 & $-0,261$ & 0,054 & 0,220 & $-0,305$ \\
\hline & & 0,003 & 0,248 & 0,077 & 0,681 & 0,305 & 0,396 \\
\hline \multirow{2}{*}{\multicolumn{3}{|c|}{$\begin{array}{c}\text { Hasil Pengujian } \\
\text { Adjusted R Square } \\
\text { F }\end{array}$}} & - & - & - & Ditolak & Ditolak \\
\hline & & & & & $\begin{array}{l}0,040 \\
0,049\end{array}$ & & \\
\hline
\end{tabular}

Sumber: Data diolah, 2015 


\section{Jurnal Keuangan dan Perbankan | KEUANGAN}

Vol. 20, No.3, September 2016: 428-437

\section{PEMBAHASAN}

Pada pengujian regresi linear berganda ditemukan bahwa capital requirement berpengaruh positif pada pengambilan risiko bank secara signifikan. Hal ini membuktikan bahwa Hipotesis 1 diterima. Temuan tersebut konsisten dengan penelitian Koehn dan Santomero (1980), Blum (1999), dan Awdeh dkk. (2011) yang menyatakan bahwa penerapan capital requirement meningkatkan pengambilan risiko bank. Namun, hal ini bertentangan dengan hasil yang diperoleh Konishi dan Yasuda (2004), Agoraki dkk. (2011), dan Berger dkk. (2014), dimana disebutkan bahwa peraturan persyaratan modal mampu mengurangi pengambilan risiko.

Salah satu alasan diberlakukannya capital requirement adalah adanya anggapan bahwa bank memilih melakukan kegiatan berisiko tinggi demi mendapatkan profit yang besar. Ini terbukti dari beberapa penelitian yang menemukan perilaku moral hazard bank saat pemerintah menjalankan program deposit insurance (Gonzales, 2005 serta Laeven dan Levine, 2009). Pemenuhan capital requirement menyebabkan penambahan modal perusahaan yang diikuti dengan meningkatnya capital buffer, sehingga akan mengurangi kemungkinan bank mengalami insolvency. Stolz (2002) menjelaskan bahwa gagasan tersebut terlalu sederhana untuk dapat mengontrol besarnya risiko yang diambil. Bank dapat meningkatkan risiko aset mereka dalam menanggapi kebutuhan modal yang tinggi, sehingga kemungkinan terjadi kenaikan pengambilan risiko semakin besar.

Bank Indonesia telah beberapa kali mengeluarkan peraturan mengenai kewajiban pemenuhan modal minimum. Pada ketentuan yang terbaru, bank diwajibkan menyediakan modal sesuai dengan profil risikonya. Kondisi ini mengharuskan bank memiliki tambahan modal untuk dapat memenuhi regulasi tersebut. Modal sebagai sumber daya yang mahal dapat mendorong bank mengambil risiko yang lebih tinggi untuk menghasilkan return yang lebih besar.
Hasil uji MRA menunjukkan bahwa struktur kepemilikan tidak mampu memoderasi pengaruh capital requirement pada pengambilan risiko bank, sehingga hipotesis kedua ditolak. Keberadaan large shareholder pada bank-bank komersial yang listed di BEI tidak mempengaruhi besarnya risiko perusahaan yang diambil dalam menanggapinya ketatnya regulasi modal. Peneliti memperkirakan bahwa tidak didukungnya Hipotesis 2 disebabkan karena laporan keuangan tidak menyajikan data yang lengkap mengenai struktur kepemilikan perusahaan. Informasi pada laporan keuangan hanya menunjukkan kepemilikan langsung (imediat) dalam perusahaan, bukan dalam tingkat kepemilikan ultimat. Tidak adanya rangkaian kepemilikan yang lengkap mengakibatkan pasar tidak dapat mengidentifikasi pola kepemilikan sesungguhnya (Siregar, 2008). Oleh karena itu, sulit untuk mengetahui apakah large shareholder yang tertera dalam laporan keuangan adalah benar-benar pemegang saham yang memiliki hak kontrol yang besar.

Lebih lanjut lagi, keberadaan struktur kepemilikan sebagai moderator dibantahkan setelah diketahui bahwa variabel ini memiliki pengaruh pada pengambilan risiko bank namun tidak berinteraksi dengan variabel capital requirement. Pernyataan tersebut didukung dari hasil uji regresi yang memperlihatkan bahwa struktur kepemilikan mempengaruhi pengambilan risiko bank secara signifikan. Sesuai dengan klasifikasi yang disampaikan oleh Sharma et al. (1981) dalam Ghozali (2006:224), dapat disimpulkan bahwa variabel struktur kepemilikan tergolong sebagai prediktor (variabel independen) dan tidak termasuk dalam jenis variabel moderasi.

Temuan penelitian ini berbeda dengan hasil riset yang didapatkan Laeven dan Levine (2009), yakni large shareholder mengkompensasikan kehilangan utilitasnya dari penerapan persyaratan modal dengan memilih berinvestasi pada portofolio yang berisiko sehingga mereka akan mempengaruhi pihak manajemen untuk meningkatkan 
pengambilan risiko bank. Tetapi, pada penelitian ini ditemukan bahwa large shareholder tidak dapat mengontrol pengambilan kebijakan perusahaan sepenuhnya. Walaupun pemegang saham memiliki hak kontrol yang besar, bukan berarti mereka dapat dengan mudah mengendalikan keputusan perusahaan.

Pada pengujian MRA, probability value interaksi antara capital requirement dan charter value yang lebih besar dari alpha $(0,05)$ mengakibatkan hipotesis ketiga ditolak. Charter value tidak mampu memoderasi pengaruh capital requirement pada pengambilan risiko bank. Hal tersebut disebabkan adanya kemungkinan perusahan-perusahaan di Indonesia tidak menganggap charter value sebagai faktor yang penting untuk diperhatikan. Informasi yang terkandung dalam charter value merupakan sesuatu yang diharapkan dapat terwujud di masa depan dan bukanlah hal yang pasti. Besarnya charter value dapat berubah-ubah tergantung dari performa perusahaan itu sendiri. Oleh karena itu, sulit memastikan apakah charter value akan dipertimbangkan bank untuk mengambil suatu keputusan, terutama dalam pengambilan risiko perusahaan.

Selain itu, dalam uji regresi linear berganda ditemukan bahwa charter value tidak memiliki pengaruh terhadap pengambilan risiko dan tidak berinteraksi dengan capital requirement. Hal tersebut menandakan bahwa charter value tergolong dalam variabel moderasi (homologizer). Dalam keadaan ini, nilai residual atau error term merupakan fungsi variabel moderator, sehingga semakin besar nilai error term, semakin kecil kekuatan hubungan dari variabel independen dan variabel dependen serta berlaku sebaliknya (Ghozali, 2006: 225).

Hasil penelitian ini berbeda dari hasil penelitian yang disampaikan Milne dan Whalley (2001) bahwa charter value mengurangi pengambilan risiko saat capital requirement diterapkan. Selain itu, hasil pengujian hipotesis ini juga berbeda dari penelitian
Hellmann dkk. (2000) yang menemukan bahwa charter value memperkuat pengaruh positif capital requirement pada pengambilan risiko bank. Dengan demikian, charter value bukanlah variabel yang dapat mempengaruhi besarnya risiko yang diambil bank.

\section{KESIMPULAN}

Berdasarkan uraian pembahasan yang disampaikan sebelumnya, diperoleh kesimpulan mengenai pengaruh capital requirement pada pengambilan risiko bank dengan struktur kepemilikan dan charter value sebagai variabel moderasi. Capital requirement berpengaruh positif pada pengambilan risiko bank. Hal ini menjelaskan bahwa makin ketatnya peraturan modal ini maka bank makin terdorong meningkatkan risiko yang diambil. Additional capital yang mahal menjadi insentif bagi bank untuk memilih proyek berisiko demi memperoleh keuntungan yang lebih besar.

Di samping itu, hasil pengujian MRA memperlihatkan bahwa struktur kepemilikan dan charter value tidak terbukti mempengaruhi hubungan capital requirement dengan pengambilan risiko. Struktur kepemilikan tidak mampu memoderasi pengaruh capital requirement pada pengambilan risiko bank. Hal ini menunjukkan bahwa large shareholder tidak dapat sepenuhnya mempengaruhi perilaku pengambilan risiko perusahaan. Di sisi lain, charter value tidak mampu memoderasi pengaruh capital requirement pada pengambilan risiko bank. Hal ini berarti charter value tidak berpengaruh pada tingkat risiko yang diambil perusahaan. Bank-bank yang go public di BEI mungkin tidak terlalu mempertimbangkan charter value sebagai faktor penting yang digunakan dalam pengambilan keputusan.

\section{SARAN}

Temuan riset ini diharapkan dapat berguna bagi pihak-pihak terkait, seperti Bank Indonesia 


\section{Jurnal Keuangan dan Perbankan | KEUANGAN}

Vol. 20, No.3, September 2016: 428-437

(BI) serta Otoritas Jasa Keuangan (OJK) sebagai tambahan informasi mengenai perilaku pengambilan risiko bank sehingga lembaga-lembaga ini dapat mengatur dan mengawasi sektor perbankan secara optimal.

\section{DAFTAR PUSTAKA}

Agoraki, M.E., Delis, M.D., dan Pasiouras, F. 2011. Regulations, Competition and Bank Rrisk-Taking in Transition Countries. Journal of Financial Stability, 7: 38-65.

Awdeh, Ali, EL-Moussawi, C., dan Machrouh F. 2011. The Effect of Capital Requirements on Banking Risk. International Research Journal of Finance and Economics, 66: 133-146.

Barry, T.A., Lepetit, L., dan Tarazi, A. 2011. Ownership Structure and Risk in Publicly Held and Privately Owned Banks. Journal of Banking and Finance, 35: 1327-1340.

Berger, Allen N., Bouwman, Christa H.S., Kick, Thomas, dan Schaeck, Klaus. 2014. Bank Risk Taking and Liquidity Creation Following Regulatory Interventions and Capital Support. Deutsche Bundesbank Discussion Paper Series, 2: 1-44.

Bigg, Anne. 2003. Bank Charter Value and Risk Taking: Evidence from Australian Banks. MAFC Research Papers, 29: 1-41.

Blüm, J.M. 1999. Do Capital Adequacy Requirements Reduce Risks In Banking?. Journal of Banking and Finance, 23: 755-771.

Burkat, M., Gromb, D., dan Panunzi, F. 1997. Large Shareholders, Monitoring, and The Value of The Firm. Quarterly Journal of Economics, 112: 693-728.

Caprio, G., Laeven, L., dan Levine, R. 2007. Ownership and Bank Valuation. Journal of Financial Intermediation, 16: 584-617.

Demsetz, R.S., Saidenberg, M.R., dan Strahan, P.E. 1996. Banks with Something to Lose: The Disciplinary Role of Franchise Value. FRBNY Economic Policy Review, 2: 1-14.

De Nicolo, G., Ariccia, G.D., Laeven, L., dan Valencia, F. 2010. Monetary Policy and Bank Risk Taking. IMF Staff Position Note, SPN/10/09.
Depkominfo. 2008. Memahami Krisis Keuangan Global: Bagaimana Harus Bersikap?. Jakarta: Badan Informasi Publik Departemen Komunikasi dan Informatika RI.

Derina, Ratna. 2011. “The Impact of Changes of Capital Regulations on Bank Capital and Portfolio Risk Decisions: A Case Study of Indonesian Banks" (thesis). Faculty of Professions: The University of Adelaide, Adelaide.

Fallah, R.S. dan Dolatabadi, H. R. 2015. Analysing the Effect of Large Shareholders' Ownership on the Decisions of Block Divestiture of Shares (Case Study: Companies Listed on the Tehran Stock Exchange). Indian Journal of Fundamental and Applied Life Sciences 2015, 5: 4872-4881.

Fisher, K., Gueyie, J., dan Ortiz, E. 2001. Risk-Taking and Charter Value of Commercial Banks' from the NAFTA Countries. The International Journal of Finance, 13: 2027-2043.

Furlong, F. T. dan Kwan, S. 2006. Sources of Bank Charter Value. Federal Reserve Bank of San Francisco Working Paper.

Gennotte, G. dan Pyle, D. 1991. Capital Controls and Bank Risk. Journal of Banking and Finance, 15: 805-824.

Ghozali, Imam. 2006. Analisis Multivariate dengan Program SPSS. Semarang: Badan Penerbit Universitas Diponegoro.

Gonzalez, Francisco. 2005. Bank Regulation and RiskTaking Incentives: An International Comparison of Bank Risk. Journal of Banking E Finance Elsevier, 29: 1153-1184.

Hellmann, T. F., Murdock, K. C., dan Stiglitz, J. E. 2000. Liberalization, Moral Hazard in Banking, and Prudential Regulation: Are Capital Requirements Enough?. American Economic Review, 90: 147-165.

Indroes, N. Ferry. 2011. Manajemen Risiko Perbankan: Pemahaman Pendekatan 3 Pilar Kesepakatan Basel II Terkait Aplikasi Regulasi dan Pelaksanaannya di Indonesia. Jakarta: PT. RajaGrafindo Persada.

Jensen, M. dan Meckling, W. 1976. Theory of the Firm: Managerial Behavior, Agency Costs, and Ownership Structure. Journal of Financial Economics, 3: 305360. 


\section{Struktur Kepemilikan dan Charter Value sebagai Pemoderasi Pengaruh Capital Requirement...}

I Gusti Ayu Nyoman Budiasih, Jessika Jesslyn, \& Anak Agung Ngurah Bagus Dwirandra

Jokipii, Terhi. 2008. BHC Buffer, Risk, and Charter Value Relationships Explored. Journal of Financial Stability, 8: 1-34.

Koehn, M. dan A. M. Santomero. 1980. Regulation of Bank Capital and Portfolio Risk. Journal of Finance, 8: 1235-1244.

Konishi, M. Dan Yasuda, Y. 2004. Factors Affecting Bank Risk Taking: Evidence fron Japan. Journal of Banking and Finance, 28: 215-232.

Laeven, L. dan Levine, R. 2009. Bank Governance, Regulation and Risk Taking. Journal of Financial Economics, 93: 259-275.

Milne, A. Dan Whalley, A. Elizabeth. 2001. Bank Capital Regulation and Incentives for Risk-Taking. Journal of Economic Literature, G21: 1-54.

Mitnick, Barry. 1996. The Hazard of Agency. Working Paper, 1: 1-48

Murray, D. 1990. The Performance Effects of Participative Budgeting, an Interpretation of Intervening and Moderating Variables. Behavioral Research in Accounting, 2: 104-123.

Ongena, Popov, dan Udell. 2013. When the Cat's Away the Mice Will Play. Does Regulation at Home Affect Bank Risk Taking Abroad?. Journal of Financial Economics, 108: 727-750.

Otoritas Jasa Keuangan. 2014. Booklet Perbankan Indonesia. Jakarta: Departemen Perizinan dan Informasi Perbankan Otoritas Jasa Keuangan.
Paligorova, T. 2010. Corporate Risk Taking and Ownership Structure. Bank of Canada Working Paper, 3: 141.

Repullo, R. 2004. Capital Requirements, Market Power, and Risk-Taking in Banking. Journal of Financial Intermediation, 13: 156-183.

Setiawan, Dharma. 2007. Analisis Terhadap Penerapan Manajemen Risiko Kredit Pada PT. Bank Ekspor Indonesia. Jurnal Ilmiah Mahasiswa Universitas Gunadarma, 5: 1-19.

Sharma, S., Durand, R., dan Gur-arie, O. 1981. Identification and Analysis of Moderator Variables. Journal of Marketing Research, 18: 291-300.

Siregar, Baldric. 2008. Ekspropiasi Pemegang Saham Minoritas Dalam Struktur Kepemilikan Ultimat. Jurnal Riset Akuntansi Indonesia, 11: 237-263.

Stolz, Stephanie. 2002. The Relationship between Bank Capital, Risk-Taking, and Capital Regulation: A Review of the Literature. Kiel Working Paper, 11: 134.

Taswan. 2012. Kepemilikan Bank dan Kepatuhan Regulasi Terhadap Risiko Perbankan yang Dimoderasi Oleh Charter Value. Jurnal Keuangan dan Perbankan, 16: 112-121. 